\title{
THE LINK OF A COACH'S PERCEPTION OF LOCUS OF CONTROL AND HIS/HER MOTIVATIONAL APPROACH TO ATHLETES
}

\author{
Mladenović Marijana ${ }^{1}$ \\ ${ }^{1}$ College of Sports and Health, Belgrade, Serbia
}

DOI: $10.5550 /$ sgia.1002035

COBISS.BH-ID 1845784

ORIGINAL SCIENTIFIC PAPER

\section{SUMMARY}

The locus of control is related to the perception of the cause of certain events. It is considered a general personality orientation, a kind of personal disposition, and can be internal and external. When the locus of control is internal, it is said to be autonomous, while external causality can be controlled (by others) or it can be impersonal (under the influence of a coincidence or luck). The approach in working with athletes can be based on supporting autonomy or behavior control. The aim of this explorative research was to determine the type of locus of control of future sports coaches, the a priori motivational approach to athletes and the potential link between the two variables. It has been presumed that coaches with an internal locus of control i.e. those who believe that they themselves are in control of events in their lives, would be more inclined, in working with athletes, to apply the approach based on supporting autonomy. The sample consisted of 122 examinees, students of coaching at the College of Sports and Health in Belgrade. The results confirmed the preliminary hypothesis and showed that the autonomous causality orientation (internal locus) dominates, linked with a supporting approach. The controlling and impersonal orientations (external locus) are related with the approach which reinforces behavior control in athletes. Especially relevant is the fact that the approach to athletes which is based on a moderate supporting of athlete autonomy is linked with all three causality orientations. It is relevant to further investigate which factors, personal and environmental, impact the orientation of the coach towards the supporting approach. Supporting athlete autonomy is an important issue, not only in a theoretical sense, but practical as well, as it has positive consequences on the psychological development and mental health of athletes, especially the younger categories.

Key words: coach's motivational approach, locus of control, supporting athletes' autonomy, control of athletes' behavior

\section{INTRODUCTION}

Starting from the basic premises of the selfdetermination theory (Deci \& Ryan, 2000; Mladenović, 2010), research has shown that the support of autonomy has a positive impact on the entire development of the personality and mental health (Ryan \& Deci, 2007). However, research has also shown that the motivational approach in sports which is based on behavior control continues to prevail (according to Mageau \& Vallerand, 2003).

In accordance with the self-determination theory, it can be presumed that the locus of control as a type of dispositional personality orientation can have a significant link with the option of the coach to direct his motivational approach to athletes towards supporting autonomy or behavior control.

The belief in the possibility or impossibility 
of controlling events and happenings in life is called locus of control. If an individual is convinced that he/she is controlling events in his/her own life, then it is said that they have an internal locus of control. When there is the conviction that some external factors are controlling events and happenings in life, there is an external locus of control (according to Cox, 2005).

Starting from these basic concepts of the theory of attribution, Deci and Ryan developed the concept of causality orientations (Deci \& Ryan, 1985). They determined causality orientations to be relatively permanent personal characteristics and made a distinction between autonomous, controlling and impersonal orientations towards the cause of events.

The autonomous causal orientations (inner locus) indicate the degree to which a person is directed towards the aspects of the environment which incite intrinsic motivation, enable optimal challenges and offer feedback on personal efficiency for a specific task. The individuals in whom these types of causal orientations are represented to the greatest degree will demonstrate much more personal initiative than individuals in whom the other two causal orientations dominate. They will seek actions which are appealing and which represent a personal challenge and will assume responsibility for their own behavior.

The controlling causal orientation (external locus) indicates the degree to which the person is directed towards awards, deadlines, egoinvolvement, structurality and directness which comes from others. Individuals in whom this causal orientation dominates rely on awards and other types of social control. Such individuals are to a large extent "adjusted" to the demands of others, and not to what they demand from themselves. Feedback information is directed towards the maintaining of self-worth and a positive self-image, and not on efficiency in responding to a specific task.

An impersonal causal orientation indicates the degree to which an individual believes that the achieving of an aim or result is entirely outside his or her control, and that a specific achievement is largely the result of coincidence or luck. Those in whom this causal orientation dominates usually feel very anxious and inefficient. They feel they cannot in any way have an impact on events or deal with the set demands or the occurring changes. They tend to be deficient on motivation and harbor the desire that everything remains "as before."

It is considered (according to Deci \& Ryan, 1985) that, to a certain extent, every person possesses all three causality orientations, so it is possible to speak about individual differences. Research studies in various areas have shown that an autonomous orientation is generally linked with greater self-respect, ego development and self-actualization (according to Deci \& Ryan, 1985) as well as greater personality integration (Koestner, Bernieri, \& Zuckerman, 1992).

To be autonomous means to manage one's self and actions independently. When autonomous, people are totally willing to do what they are involved with and perform with interest and dedication. Behavior is controlled when the individual is under pressure to do something. When there is control, there is no subjective sense of agreement to perform (Ryan \& Deci, 2007).

The coach base his motivational approach on supporting the autonomy of athletes, if he respects and values the personality of each athlete. He also stimulates the personal responsibility of the athlete by offering the possibility of choice within the framework of the given rules, and offering explanations for the set tasks, as well as enabling the athlete to develop initiative and autonomy in work (Mladenović, 2008). Such a coach has the ability of empathy and is capable of seeing the point of view of another person. The feedback on the competence of the athlete regarding the specific task is always in an "informing" and not a controlling form (Lazarević, 2001).

Behavior control is related to the pressure to behave and think in a certain way (Deci \& Ryan, 1985). It includes the use of threats, physical force, supervising, psychological control, inducing the feeling of guilt and self-criticism, as well as the application of material rewards and feedback information on competence in a controlling way (Mageau \& Vallerand, 2003).

In the context of sports, it is presumed that 
coaches who a priori on the level of personal traits manage different orientations on the cause of events would have a different attitude towards athletes.

The coaches who believe that they impact events in their own lives will probably be convinced that they can exert influence on their athletes as well, that is, on their personal and sports development. These "sorts" of coaches will essentially respect individual differences, the inner states and feelings of athletes and support their autonomy in work. In this way, athletes are enabled to develop their locus of control and feelings of personal responsibility themselves. Fostering the approach which is based on respect and valuing the athlete is significant, not only for achieving top sports results but also for the mental health and development of young athletes.

The coaches who believe that events in their lives largely depend on certain external factors, such as other people, coincidence or luck, will be more inclined to demonstrate a much larger degree of control in working with athletes. Coaches such as these put more value on the use of control and focus more attention on authority. They will endeavor to secure the compliance of the athlete, to shape their way of thinking and behavior and will use extrinsic rewards for every progression in that sense.

The motivational approach of a coach in working with athletes is especially significant in working with younger categories of athletes. It is important theoretical as well as practical issue.

The aim of this explorative research was to test if there is a link between the locus of control and the coach's motivational approach towards athletes.

According to the self-determination theory, the general assumption was that future sports coaches who believe that they themselves manage events in their lives (the autonomous causality orientation - inner locus) would be more inclined to develop a motivational approach which is based on supporting the autonomy of athletes. On the other hand, it is assumed that the controlling and impersonal causality orientations will be linked with favoring the motivational approach which is based on controlling athletes' behavior.

\section{METHOD}

\section{Sample}

The sample consisted of 122 examinees, first and second-year students of the Sports College of Belgrade, from the sports coaching department. The higher percentage of the examinees was males (78.7\%), with $21.3 \%$ female examinees. The age of the examinees was from 19 to 38. More than half of the examinees $(54.1 \%)$ were aged between 19 and 22, while only $10 \%$ examinees were over 28 .

\section{Variables}

Two variables were used - the causality orientation of the coach and the motivational approach. The causality orientation was operationalized as autonomous, controlling and impersonal. The motivational approach of the coach was operationalized as high autonomy, moderate autonomy, moderate control and high control of athlete behavior.

\section{Procedure}

The respondents participated in the research voluntarily and had the option to leave at any chosen point in time. In the instructions for filling out the questionnaire, the respondents were told they were participating in a research which has the aim to test how future sports coaches reason about various topics. It was stressed that there are no correct or wrong answers, but that it is important to respond honestly to the items, as well as that participation in the research or the nature of the responses given in the questionnaire will in no way impact the respondent's standing. Thus a potential social suitability of the response was avoided, as the questionnaires were filled out during lectures in Psychology of Sports and the Psychological Preparations of Athletes.

\section{Instruments}

Two instruments were used in the research.

The General Causality Orientation Scale was used to gauge causal orientations. The original instrument contains 12 vignettes and 36 items (Deci \& Ryan, 1985). Each vignette 
describes a typical social situation or an achievement situation and is backed up with descriptions of possible reactions to situations which reflect an autonomous, controlling or impersonal causal orientation. On a sevendegree Likert-type scale, the examinee indicated to what extent it is possible to react in the described situation in each of the depicted ways. The scores on each of the three subscales (autonomous, controlling, and impersonal) reflected the relative representation of causal orientations. The reliability of the instrument in this research has been determined by Cronbach's alpha equal to .75 .

To test a coach's motivational approaches, a Scale of the Motivational Orientation of the coach was constructed for the needs of this research. The scale was modeled after similar instruments intended to test the motivational approach of individuals who are in some sort of position of authority, such as for example teachers (Deci, Schwartz, Sheinman \& Ryan, 1981; Reeve, Bolt, \& Cai, 1999). The coaches' scale of motivational orientation consisted of 8 vignettes and 32 items. The vignettes described potential situations in which coaches can find themselves while working with younger athletes. An example is this story: "Marko is 10 years old and has been training football successfully. During the last two weeks, however, he has become in some way disinterested and indifferent. He goes to training, but it is obvious he doesn't put much effort in it. A phone conversation with his mother lacked to disclose any useful information. The best thing for his coach to do is..." For every described situation in one of the 8 stories, four possible ways of reacting were on offer: high autonomy ("to make it clear to him that it's not the end of the world because he's not training well and to try to help him to discover the cause of his disinterest and indifference"), moderate autonomy ("to help him cope with the game and with the effort of the other children and to encourage him to keep up with the others"), moderate control ("it should be made clear to him that it is important to put forth more effort if he wishes to progress"), high control("to leave him to train additionally after every training session, until he gets better"). The examinee was asked to express his or her opinion on the seven-degree Likert-type scale on how appropriate each of the four described reactions was. The scale was applied for the first time in this research study and at present, except for reliability, no other metric properties are known The value of Cronbach's alpha was .81.

\section{Statistical analysis}

The reliability of the instruments was tested out by the Cronbach alpha. For each of the three types of causal orientation and all four variants of the coach's motivational approach, the arithmetic mean and standard deviations were calculated. The significance of the arithmetic mean was tested by the application of the t-test. The degree of linkedness of causal orientation and motivational approaches was determined by calculating the Pearson's coefficient correlation. Data processing was done alternatively as well - without an outlier.

\section{RESULTS}

As Diagram 1 shows, the testing of the locus of control showed that the autonomous orientation was represented in future sports coaches to the largest degree $(\mathrm{M}=5.20$; $\mathrm{SD}=.67 ; \mathrm{t}=85.120 ; \mathrm{p}<.01)$, followed by controlling $(\mathrm{M}=4.58 ; \mathrm{SD}=.66 ; \mathrm{t}=76.520 ; \mathrm{p}<.01)$, while the impersonal causality orientation was present the least $(\mathrm{M}=2.74 \mathrm{SD}=.95 ; \mathrm{t}=31.747$ $\mathrm{p}<.01)$. All means values differences were significant, and the analysis was done without outliers as well (Addendum 1).

The obtained results indicate that future coaches to the largest degree possess an inner locus of causality i.e. the belief that they have control over events in their lives. To a somewhat lesser degree is present the belief that external factors (e.g. other people) manage their lives. Impersonal causality, as the reflection of some kind of learned helplessness, is represented the least as a general orientation with young coaches.

The results further indicate that a high orientation towards autonomy dominates as an approach to athletes $(\mathrm{M}=5.52 ; \mathrm{SD}=.71$; $\mathrm{t}=86.561 ; \mathrm{p}<.01)$. The approach which is based on moderate control of athlete behavior 
follows $(\mathrm{M}=5.12 ; \mathrm{SD}=0.83 ; \mathrm{t}=67.618 ; \mathrm{p}<.01)$, then the approach which is characterized by a moderate support of autonomy $(\mathrm{M}=4.95$; $\mathrm{SD}=.87 ; \mathrm{t}=62.544 ; \mathrm{p}<.01)$, while a high orientation towards the control of athlete behavior $(\mathrm{M}=3.79 ; \mathrm{SD}=.91 ; \mathrm{t}=45.929 ; \mathrm{p}<.01)$ is on the last place. (Diagram 2)

DIAGRAM 1

The locus of control of sports coaches

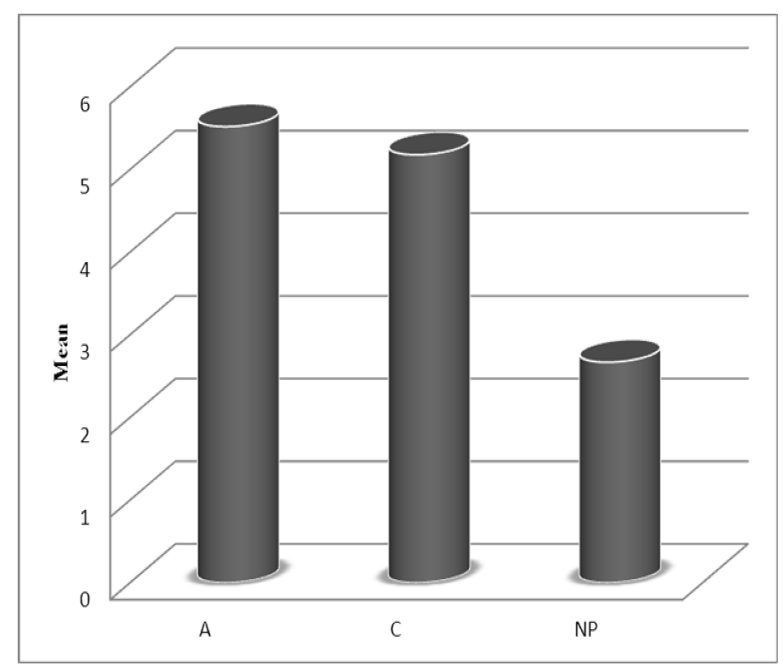

Legend: $\mathbf{A}$ - autonomous causality orientation (inner locus); C - controlling causality orientation (external locus); NP impersonal causality orientation;

\section{DIAGRAM 2}

Sports coaches' motivational approaches to athletes

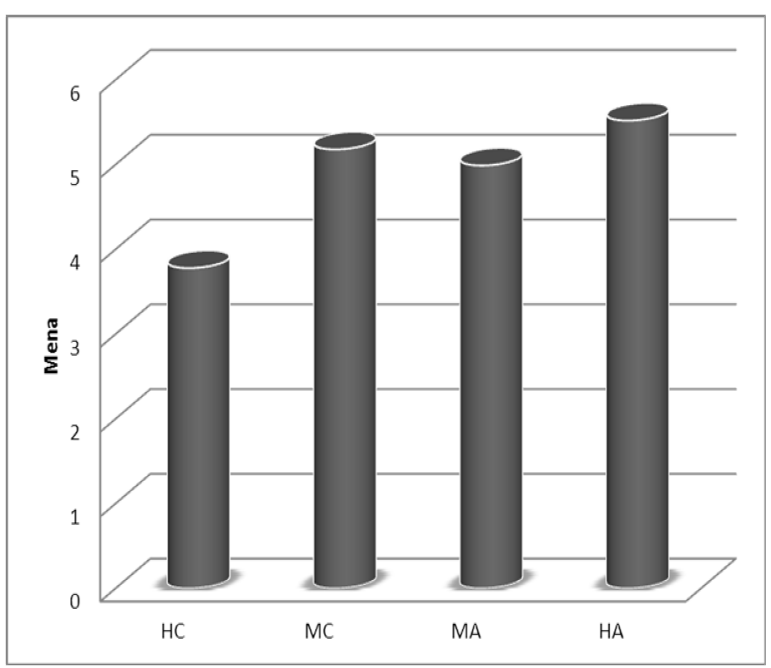

Legend: HA - high autonomy; MA - moderate autonomy; HC - high control; MC moderate control;
The values of the t-test show that the means values are statistically significant, but the high values of the standard deviation point to potential individual differences, especially in regards to the approach which is based on athlete control. Thus the analysis was completed alternatively as well - without outliers. By removing the outliers, the individual variations in responding to items which measure four approaches to athletes are reduced, though the entire approach to athletes remains unchanged (Addendum 2).

The results of the correlational analysis show that approaches to athletes are linked with causality orientations (Table 1). The correlational analysis was also done without outliers (Table 2), but except for specific values of certain coefficients of correlations, the results did no change significantly.

The approach which is based on a moderate or high support of autonomy of athletes is significantly linked with the autonomous causality orientation. The controlling approach of the coach, regardless whether it involves a high or moderate control of athlete control, significantly correlates with controlling and impersonal causality orientations. However, the approach of a coach who moderately supports the autonomy of an athlete is significantly linked not only with the autonomous, but also with the other two causality orientations - controlling and impersonal.

The approach to athletes is not just a theoretical, but also a practical issue. The relationship between a coach and an athlete is a reciprocal process in which the coach and the athlete mutually influence each other. Coaches do not behave in the same way towards all athletes. The behavior of a coach in specific situations is a reaction to perceived behavior and the motivation of the athlete. However, a personal causality orientation of the coach, as a more permanent dispositional orientation, can significantly impact the a priori attitude regarding the most effective approach to athletes.

The results of this research show that future sports coaches to the largest degree have an internal locus of control, i.e. they believe that the events in their lives are under 
their control. In turn, they attribute the effects of their activities to causes such as abilities and vested effort. Such a causality orientation in life, generally speaking, is linked with the approach to athletes which is operationalized as a high orientation towards autonomy. This finding confirms the basic hypothesis of the

TABLE 1.

The correlation of the motivational approach to athletes with the causality orientations of coaches $(N=122)$ research. Coaches who believe they have control over events in their lives will most probably, regardless of the nature of external influences, retain the conviction that the valuing of the personality of the athletes and support for their autonomy is relevant and necessary.

\begin{tabular}{lccc}
\hline \multirow{2}{*}{$\begin{array}{l}\text { Motivational approach } \\
\text { of coach }\end{array}$} & \multicolumn{3}{c}{ Causality orientations } \\
\cline { 2 - 4 } & $\begin{array}{c}\text { autonomy } \\
\text { (inner locus) }\end{array}$ & $\begin{array}{c}\text { control } \\
\text { (external locus) }\end{array}$ & $\begin{array}{c}\text { impersonal } \\
\text { causality }\end{array}$ \\
\hline High autonomy & $\mathbf{. 3 5 9}$ & -.072 & .108 \\
\hline Moderate autonomy & $\mathbf{. 2 5 2}$ & $\mathbf{. 3 2 0}$ & $\mathbf{. 3 9 0}$ \\
\hline Moderate control & .131 & $\mathbf{3 9 4}$ & .292 \\
\hline High control & .028 & $\mathbf{. 3 3 3}$ & $\mathbf{. 4 0 2}$ \\
\hline $\mathrm{p}<.01$ & & &
\end{tabular}

TABLE 2.

The correlation between the motivational approach to athletes and causality orientations of coaches (without outliners, $N=101$ )

\begin{tabular}{lccc}
\hline \multirow{2}{*}{$\begin{array}{l}\text { Motivational approach } \\
\text { of coach }\end{array}$} & \multicolumn{3}{c}{ Causality orientations } \\
\cline { 2 - 4 } & $\begin{array}{c}\text { autonomy } \\
\text { (inner locus) }\end{array}$ & $\begin{array}{c}\text { control } \\
\text { (external locus) }\end{array}$ & $\begin{array}{c}\text { impersonal } \\
\text { causality }\end{array}$ \\
\hline High autonomy & $\mathbf{. 3 0 0}$ & -.090 & -.011 \\
\hline Moderate autonomy & .171 & $\mathbf{2 6 8}$ &. $\mathbf{2 1 6}$ \\
\hline Moderate control & .065 & $\mathbf{. 3 6 7}$ &. $\mathbf{2 6 8}$ \\
\hline High control & -.135 & $\mathbf{. 2 2 0}$ & .210 \\
\hline $\mathrm{p}<. \mathbf{0 1}$ & & &
\end{tabular}

With one part of the tested future sports coaches, it was shown that the causality orientation according to which responsibility for life events rests on factors outside the personality itself - other people, coincidence or luck, a "higher power" - dominated. Such a dispositional orientation can extend from the undeniable fact that the individual is not always the sole factor which determines the results from life events, to the concept of learned helplessness according to which every activity depends on some impersonal force on which there is no impact. Future sports coaches which adopt such an external locus on the level of personality disposition, regardless whether it's a controlling or impersonal orientation, will be more inclined in practical work with athletes to apply the negative approach, giving an advantage to behavior control.

However, especially significant is the result that the approach which is based on a moderate support of athlete autonomy correlates with all three causality orientations. After excluding the outliers from the analysis, what remains is only a link with controlling and impersonal causality orientations. The link of the approach to athletes which is based on a moderate support of autonomy and the external locus of control appears at first incompatible, but this correlation should be further investigated.

A finding such as this in the psychological sense is very encouraging, as it points to the fact that young people who in their lives are faced with the impossibility to entirely impact the results of their own activities, events and 
happenings, show tendencies, on the level of personality disposition, to influence others they can have an impact on, by applying a different approach from the one they themselves were exposed to.

\section{CONCLUSION}

A motivational approach to working with athletes, especially younger categories, can have far-fetching consequences not only on future sports successes of young athletes but also on their entire mental development and mental health.

The results of this research have shown that future sports coaches who at the level of personal disposition have an internal locus of control (autonomous causality orientation) show an a priori attitude that, in working with athletes, respect, valuing and supporting of athlete autonomy should be shown. Future sports coaches who on the level of general dispositional characteristics incline towards an external locus of control (controlling and impersonal causality orientation) favor the approach towards athletes which is based on behavior control.

For further empirical research, but also for a systematic training of future sports coaches, of relevance is the fact from this research which points to the existing of a link between the external locus of control and the tendency to apply the approach which is based on a moderate supporting of autonomy in working with athletes.

\section{ADDENDUM 1.}

Causality orientation of sports coaches (without outliers, $N=101$ )

\begin{tabular}{lcccc}
\hline Causality orientation & $\mathrm{M}$ & $\mathrm{SD}$ & t-test & $\begin{array}{c}\text { Degrees } \\
\text { of freedom }\end{array}$ \\
\hline Autonomy (inner locus) & 5.29 & .49 & $\mathbf{1 0 7 . 7 3 6}$ & 100 \\
\hline Control (external locus) & 4.57 & .61 & $\mathbf{7 5 . 4 4 0}$ & 100 \\
\hline Impersonal causality & 2.67 & .81 & $\mathbf{3 3 . 2 5 0}$ & 100 \\
\hline $\mathbf{p}<. \mathbf{0 1}$ & & & &
\end{tabular}

ADDENDUM 2.

Predictor variables significance for some trainer job satisfaction prediction

\begin{tabular}{lcccc}
\hline $\begin{array}{l}\text { Motivational approach } \\
\text { of coaches }\end{array}$ & $\mathrm{M}$ & $\mathrm{SD}$ & $\mathrm{t}$-test & $\begin{array}{c}\text { Degrees } \\
\text { of freedom }\end{array}$ \\
\hline High autonomy & 5.52 & .63 & $\mathbf{8 7 . 2 4 5}$ & 100 \\
\hline Moderate control & 5.18 & .76 & $\mathbf{6 7 . 9 0 7}$ & 100 \\
\hline Moderate autonomy & 4.99 & .76 & $\mathbf{6 5 . 5 1 0}$ & 100 \\
\hline High control & 3.78 & .76 & $\mathbf{4 9 . 5 1 6}$ & 100 \\
\hline $\mathbf{p}<. \mathbf{0 1}$ & & & &
\end{tabular}

\section{REFERENCE:}

Cox, R.H. (2005). Sport Psychology. [Psihologija sporta. In Croat.]. Jastrebarsko: Naklada Slap

Deci, E.L., Schwartz, A.J., Sheinman, L. \& Ryan, R.M. (1981). An instrument to assess adults' orientations toward control versus autonomy with children: Reflections on intrinsic motivation and perceived compe- tence. Journal of Educational Psychology, 73(5), pp. 642-650.

Deci, E.L. \& Ryan R.M. (1985). The General Causality Orientation Scale: Self-

Determination in Personality. Journal of Research in Personality, 19, pp. 109-134.

Deci, E.L. \& Ryan, R.M. (2000). Self-

Determination Theory and the Facilitation of Intrinsic Motivation, Social Development and Well-Being. American Psychologist, 55, pp. 68-78. 
Koestner, R., Bernieri, F., \& Zuckerman, M. (1992). Self-determination and consistency between attitudes, traits, and behaviors. Personality and Social Psychology Bulletin, 18, pp. 52-59.

Lazarević, Lj. (2001). Psychological foundations of physical education. Fourth edition. Psihološke osnove fizičke kulture. In Serbian.]. Beograd: Viša škola za sportske trenere.

Mageau, G.A. \& Vallerand, R.J. (2003). The Coach-Athlete relationship: A Motivational Model. Journal of Sport Sciences, 21, pp. 883904.

Mladenović, M. (2008). Extrenal and internal motivation in sport. [Spoljašnja i unutrašnja motivacija u sportu. In Serbian.]. Nova sportska praksa, 1-2, pp. 26-36.
Mladenović, M. (2010). Self-motivation. [Samomotivacija. In Serbian.]. Beograd: Zadužbina Andrejević.

Reeve, J., Bolt, E. \& Cai, Y. (1999). Autonomy-supportive teachers: How they teach and motivate students. Journal of Educational Psychology, 91, pp. 537-548.

Ryan, R.M. \& Deci, E.L. (2007). Active Human Nature: Self-Determination Theory and the Promotion and Maintenance of Sport, Exercise and Health. In M.S.

Hagger, \& N.L.D. Chatzisarantis (Eds): Intrinsic Motivation and Self-Determination in Exercise and Sport. Champaign, IL: Human Kinetics, pp. 1-19.

Received: July, $23^{\text {rd }} 2010$ Accepted: December, $13^{\text {th }} 2010$

Correspodence to: Marijana Mladenović, $\mathrm{PhD}$

Branka Ćopića 5

11160 Belgrade

Serbia

Phone: +38162 216126

+381638089333

E-mail: marijana.mladenovic@gmail.com 


\title{
POVEZANOST TRENEROVE PERCEPCIJE LOKUSA KONTROLE I MOTIVACIONOG PRISTUPA SPORTISTIMA
}

\author{
Mladenović Marijana ${ }^{1}$ \\ ${ }^{1}$ Visoka sportska i zdravstvena škola, Beograd, Srbija
}

Polazeći od osnovnih premisa teorije samodeterminacije (Deci \& Ryan, 2000; Mladenović, 2010), istraživanja su pokazala da podržavanje autonomije pozitivno utiče na cjelokupan razvoj ličnosti i mentalno zdravlje (Ryan \& Deci, 2007). Međutim, istraživanja takođe pokazuju i da u sportu uglavnom i dalje preovlađuje motivacioni pristup trenera koji se zasniva na kontroli ponašanja (prema Mageau \& Vallerand, 2003) .

U skladu sa teorijom samodeterminacije, može se pretpostaviti da bi lokus kontrole kao jedna vrsta dispozicione orijentacije ličnosti mogao značajno da bude povezan sa opredeljenjem trenera da svoj motivacioni pristup sportistima usmjeri u pravcu podržavanja autonomije ili kontroli ponašanja.

Lokus kontrole određuje se kao uvjerenost u mogućnost da se utiče na događaje i zbivanja. Smatra se opštom orijentacijom ličnosti, koja je jedna vrsta personalne dispozicije (Deci \& Ryan, 1985). Kada je lokus kontrole unutrašnji kaže se da je autonoman, dok spoljašnja uzročnost može biti kontrolisana (drugim osobama) ili nepersonalna (pod uticajem "više sile").

Trener koji vjeruje da može da utiče na događaje u svom životu biće uvjeren da može da utiče i na svoje sportiste, na njihov optimalan sportski i psihički razvoj. Takav trener biće tolerantniji na individualne razlike među sportistima, postavljace optimalne izazove pred svakog sportistu i podržavaće razvoj lične odgovornosti.

Trener kod kojeg dominira uverenje da njegovim životom upravljaju neki spoljašnji faktori biće sklon da i sam u radu sa sportistima demonstrira kontrolu ponašanja. Iako kontrola ponašanja, nadzor, pritisak, primjena kažanjavanja itd. mogu naizgled brzo i efikasno da utiču na ponašanje sportista, dugoročno ne obez- bjeđuju uslove za optimalan sportski i psihički razvoj mladih sportista.

Cilj ovog eksplorativnog istraživanja bio je da se utvrdi kakav lokus kontrole postoji kod budućih sportskih trenera, kakav je a priori pristup sportistima i da li između te dvije varijable postoji povezanost. Polazeći od glavnih premisa teorije samodeterminacije, postavljena je glavna hipoteza da će treneri sa unutrašnjim lokusom kontrole tj. oni koji vjeruju da sami kontrolišu događaje u svom životu, biti skloniji da u radu sa sportistima primjenjuju pristup koji se zasniva na podržavanju autonomije.

Uzorak se sastojao od 122 ispitanika, studenata prve $\mathrm{i}$ druge godine Visoke sportske $\mathrm{i}$ zdravstvene škole strukovnih studija iz Beograda, smjer - sportski trener. Najveći procenat ispitanih bio je muškog pola $(78,7 \%)$, a ispitanika ženskog pola bilo je $21,3 \%$. Starost ispitanika bila je od 19 do 38 godina. Više od polovine ispitanih $(54,1 \%)$ bilo je starosti od 19 do 22 godine, dok svega 10\% ispitanika ima preko 28 godina.

Za ispitivanje lokusa kontrole upotrebljena je Skala opšte orijentacije uzročnosti (General Causality Orientation Scale). Vrijednost Kronbahove alfe u ovom istraživanju iznosila je 0,75 . Za ispitivanje motivacionih pristupa trenera konstruisana je Skala motivacione orijentacije trenera. Pouzdanost instrumenta bila je zadovoljavajuća (Kronbahova alfa 0,81).

Za svaki tip kauzalne orijentacije i svaki od četiri motivaciona pristupa izračunavane su aritmetičke sredine i standardne devijacije. Značajnost aritmetičkih sredina provjeravana je t-testom. Povezanost kauzalnih orijentacija i motivacionih pristupa provjeravana je korelacionom analizom.

Ispitivanje lokusa kontrole pokazalo je da je kod budućih sportskih trenera u najvećem stepenu zastupljena autonomna (AS $=$,20; $\mathrm{SD}=0,67 ; \mathrm{t}=85,120 ; \mathrm{p}<0,01)$, pa kontrolišuća 
(AS=4,58; $S D=0,66 ; t=76,520 ; p<0,01)$, dok je nepersonalna orijentacija uzročnosti najmanje prisutna $\quad(\mathrm{AS}=2,74 ; \quad \mathrm{SD}=0,95 ; \quad \mathrm{t}=31,747$; $\mathrm{p}<0,01)$. Sve dobijene aritmetičke sredine su statistički značajne.

Rezultati dalje pokazuju da kod budućih sportskih trenera kao pristup sportistima dominira visoka orijentacija na autonomiju (AS=5,52; $\mathrm{SD}=0,71 ; \mathrm{t}=86,561 ; \mathrm{p}<0,01)$. Slijedi pristup koji se zasniva na umjerenoj kontroli ponašanja sportista $(\mathrm{AS}=5,12 ; \quad \mathrm{SD}=0,83$; $\mathrm{t}=67,618 ; \mathrm{p}<0,01)$, pa pristup koji karakteriše umjereno podržavanje autonomije ( $\mathrm{AS}=4,95$; $\mathrm{SD}=0,87 ; \mathrm{t}=62,544 ; \mathrm{p}<0,01)$, dok je visoka orijentacija na kontrolu ponašanja sportista $(\mathrm{AS}=3,79 ; \quad \mathrm{SD}=0,91 ; \mathrm{t}=45,929 ; \mathrm{p}<0,01)$ na poslednjem mestu.

Korelaciona analiza pokazuje da postoji značajna povezanost između unutrašnjeg lokusa kontrole i pristupa koji se zasniva na visokom $(0,359 ; \mathrm{p}<0,01)$ i umjerenom $(0,252$; $\mathrm{p}<0,01)$ podržavanju autonomije sportista.
Spoljašnji lokus kontrole značajno i pozitivno korelira sa pristupom koji se zasniva na visokoj $(0,333 ; \mathrm{p}<0,01)$ i umerenoj $(0,394 ; \mathrm{p}<0,01)$ kontroli ponašanja, ali i sa umjerenim podržavanjem autonomije sportista $(0,320 ; \mathrm{p}<0,01)$. Uvjerenost u nepersonalnu kauzalnost u sopstvenom životu najviše je povezana sa orijentacijom trenera na kontrolu ponašanja sportista $(0,402 ; \mathrm{p}<0,01)$.

Za dalja empirijska istraživanja, ali i za praktičan rad na edukaciji budućih sportskih trenera, značajna je povezanost pristupa koji se zasniva na umjerenom podržavanju autonomije sportista sa sve tri orijentacije uzročnosti. Takav nalaz je u psihološkom smislu vrlo ohrabrujući, jer ukazuje da mladi ljudi koji se suočavaju sa nemogućnošću da u potpunosti utiču na događaje u svom životu, pokazuju tendenciju da prema onima na koje imaju prilike da utiču primjene drugačiji pristup od onog kojem su sami bili podvrgnuti.

Ključne riječi: motivacioni pristup trenera, lokus kontrole, podržavanje autonomije sportiste, kontrola ponašanja sportsite. 